\title{
ANALISIS MINAT BELI WANITA TERHADAP PRODUK TAS BERMEREK ORIGINAL DI TENGAH KOMODITI PRODUKSI TAS BERMEREK TIRUAN PRODUKSI PRODUSEN LOKAL
}

\author{
Dzuha Hening Yanuarsari \\ Program Studi Desain Komunikasi Visual \\ Fakultas Ilmu Komputer, Universitas Dian Nuswantoro Semarang \\ dzuhahening@yahoo.com
}

\begin{abstract}
Abstrak
Semakin kompleksnya perkembangan dunia fashion di masyarakat menimbulkan penambahan citra estetik bagi setiap barang-barang yang dikenakan sehari-hari. Tas merupakan produk yang sering dilirik oleh wanita. Selain dari segi fungsionalitasnya, tas sekarang mulai digunakan wanita sebagai barang pelengkap padu padan busana untuk menyelaraskan gaya maupun meningkatkan citra kelasnya dimasyarakat. Semakin banyak value yang dikeluarkan untuk membeli sebuah tas maka semakin tinggi penilaian masyarakat akan citra kelas terhadap dirinya. Tas mampu menimbulkan fetisisme tersendiri di masyarakat tidak hanya pada kalangan wanita kebanyakan, tetapi juga kalangan pria. Dari fenomena-fenomena tersebut akhirnya memunculkan banyak produsen-produsen lokal yang melirik peluang tersebut dengan memproduksi tas replika yang memiliki hereditas yang hampir sama dengan tas bermerek produksi produsen aslinya. Dikaji dari klasifikasi modalnya, maka posisi nilai dari pemakaian tas disini termasuk kedalam modal sosial dimana kepemilikan tas mampu menggusung citra diri seseorang. Namun jika menilik dari fenomena kemunculan banyak produsen lokal yang memproduksi tas berkelas replika bisa dihubungkan dengan hukum Gestalt yakni hukum persamaan dan kontinuitas. Sedangkan jika ditilik dari sistem objek yang membawanya dalam kasus ini termasuk kedalam The Non-Functional System dimana objek tidak hanya dilihat sebatas fungsionalitasnya saja akan tetapi ranah ekspresinya juga yang mana jika memakai objek tersebut (tas) mampu menjembatani individu berdasarkan kompromi dari pengalaman, keinginan dan cita-citanya.
\end{abstract}

Kata Kunci : Fashion, Minat Beli, Tas

\section{PENDAHULUAN}

Tas merupakan salah satu produk pelengkap fashion yang tidak bisa lepas dari pencitraan diri seorang wanita. Wanita rela mengeluarkan uang melebihi kapasitas pendapatan mereka hanya untuk mendapatkan produk tas yang sesuai dengan selera hati mereka. Semakin tinggi nilai harga yang dikeluarkan untuk sebuah tas maka akan semakin tinggi tingkat penghargaan masyarakat yang menilai pemilik tas tersebut sebagai kaum yang berkelas. Disini muncul banyak inspirasi para desainer tas di dunia untuk memproduksi tas dengan bahan, kualitas, bahkan model dengan produksi yang begitu limited edition hanya untuk menghasilkan tas berkualitas super yang akan diburu oleh banyak wanita. Hingga akhirnya muncul berbagai merek tas ternama yang begitu digemari dan dicari oleh masyarakat seperti Chanel, Hermes, Louis Vuitton, Prada, dan lain sebagainya. 
Tas sejak jaman dahulu memang lebih dikenal akan fungsi dan muatan kapasitasnya saja, namun semakin kesini nilai estetika dari sebuah tas dan fetisisme wanita terhadap tas mulai dipertimbangkan sebagai fitur yang bisa diolah oleh para produsen untuk menghasilkan keuntungan yang sebesar-besarnya. Karena sering banyaknya tingkat permintaan konsumen yang meledak sedangkan banyak produsen tas berkelas yang memproduksi tas mereka hanya beberapa buah saja bahkan ada yang bisa dihitung oleh jari membuat permasalahan tersendiri. Dari permasalahan tersebut, akhirnya bermunculan produksi-produksi tas dengan desain yang sama di masyarakat namun dibandrol dengan harga yang rata-rata bisa dijangkau oleh masyarakat. Tas-tas tersebut biasanya dibuat oleh produsen lokal yang ingin memanfaatkan keadaan tersebut sebagai ladang bisnis yang menguntungkan. Kebanyakan tas hasil produksi mereka memang memiliki desain dan warna yang sama namun, kualitas dan bahan yang dimiliki belum tentu sebanding dengan tas-tas yang diproduksi oleh produsen pemegang merek asli yang bisa dibilang karena faktor harga yang membrandol tas dan pemegang paten merek tersebut. Namun, disini muncul juga permasalahan bagi pihak produsen pemegang paten merek tas berkelas yang asli atau original. Bagi konsumen yang menginginkan barang yang sama dengan kualitas dan bahan yang menyerupai tas berkelas yang asli, produsen lokal juga sanggup menyediakannya meskipun dibrandol dengan harga yang lumayan tinggi tetapi masih tetap berada di bawah kisaran harga tas berkelas yang asli.

Ladang bisnis dalam kehidupan masyarakat sosialita dan modern dewasa ini memang seringkali menjadikan perdebatan dan sengketa tersendiri. Masyarakat dengan tingkatan kelas yang berbeda bisa saja saling berebut pangsa pasar yang didalamnya seringkali terjadi semacam simbiosis parasitisme. Simbiosis ini memang merugikan atau membunuh salah satu pihak namun pihak yang lain seringkali merasa acuh asal mereka bisa memperoleh keuntungan yang mereka harapkan. Seperti layaknya kasus pembajakan lagu, CD atau bahkan warisan kebudayaan yang masih serumpun. Disini nilai perilaku, gaya hidup yang mendasari sebab akibat pola perilaku mereka yang terstruktur baik secara eksternal maupun internal layaknya habitus, atau bahkan sistem objek yang membangun penilaian masyarakat akan suatu benda keseharian mereka perlu dibahas dan dipertanyakan. Oleh sebab itu, penulis mengambil tema ini guna membahas isu-isu yang tengah berkembang ditengah masyarakat khususnya kaum wanita sosialita dan modern karena tas menjadi salah satu dominasi produk di pasaran yang pangsa pasarnya seringkali menjadi lirikan wanita ketika sedang berbelanja.

Fokus kajian dalam tujuan penelitian ini yakni seputar isu bisnis produksi antara tas berkelas produk original pemegang paten merek asli dengan tas berkelas replika produksi produsen lokal yang ingin melihat dan memanfaatkan potensi pasar yang tengah berkembang. Digali dengan pembahasan melalui sudut pandang proses Capital, Habitus dan Sistem Objek yang mendasarinya serta dikorelasikan dengan Teori Gestalt. Hal ini nantinya berfungsi untuk melihat sudut pandang khalayak wanita selama ini dalam memilih produk. Dari berbagai tingkatan kelas strata yang ada pada wanita. 


\section{METODE ANALISIS}

Metode analisis yang digunakan adalah metode deskriptif-kualitatif yang bertujuan untuk menganalisis lebih jauh adakah peluang, korelasi atau fenomena yang mendasari kemunculan produsen-produsen lokal yang memproduksi tas-tas yang mirip diproduksi oleh produsen tas berkelas atau bermerek.

\section{HASIL DAN PEMBAHASAN}

\subsection{Minat Beli Wanita terhadap Tas}

Tas merupakan salah satu komoditas paling dicari wanita ketika berada dipusat perbelanjaan. Produk subtitusi pelengkap fashion ini mampu menghipnotis kaum perempuan untuk mengambil keputusan membeli tas sesuai selera mereka bahkan menjadikannya sebagai barang koleksi. Tas seringkali mengalihkan perhatian wanita yang mampu menimbulkan fetisisme berlebihan dalam mengambil keputusan membeli atau memiliki sebuah tas sesuai harapan mereka.

Perhatian, sebagai salah satu aktifitas psikis, dapat dimengerti sebagai keaktifan jiwa yang dipertinggi. Jiwa itupun semata-mata tertuju kepada suatu objek (benda/hal) ataupun sekumpulan objek-objek (A. Gazali, 1970: 116).

Perhatian wanita terhadap tas juga menjembatani keinginan atau hasrat wanita untuk tampil cantik dihadapan para pria atau lingkungannya. Sisi feminisme bahkan luxurious bisa dimunculkan lewat kepemilikan barang ini. Seperti kisah salah satu selebritas di Indonesia yakni Angel Helga yang rela membeli satu buah tas dengan harga ratusan juta rupiah menunjukan identitas kegemaran atau kegilaannya (fetisisme) akan barang tersebut. Semakin tinggi kelas dari seorang wanita biasanya kepemilikan akan barang dalam kehidupan sehari-harinya akan semakin bernilai tinggi dengan kualitas barang yang super.

Salah satu cara kita dalam membedakan sebuah tas bermerek yang asli dengan tas bermerek yang palsu adalah pengalaman kita dalam berbelanja. Semakin sering kita membeli tas bermerek maka akan semakin mahir kita dalam membedakannya baik dari segi material, kualitas, dan kuantitas harga yang dibandrol. Biasanya tas bermerek yang asli akan dibandrol dengan harga yang fantastis karena disertai dengan sertifikat pembelian. Sedangkan dari segi material dan kualitas, tas bermerek yang asli biasanya menggunakan material yang lebih keras dan kualitas pemakaianya bisa tahan cukup lama. Salah satu contohnya yakni analisis pada tas bermerek produksi Gucci berikut ini:

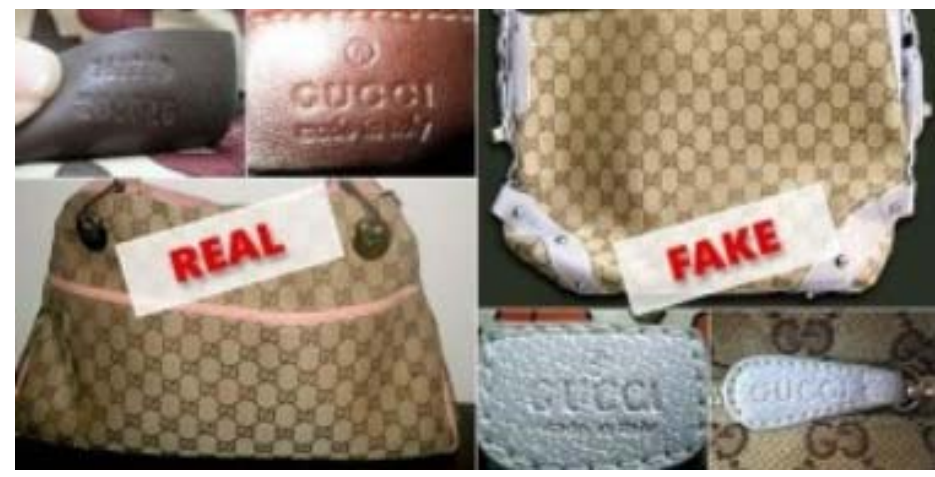

Gambar 1. Label tas Gucci

Sumber : http://blackoutlet.ro/fake-gucci-2/ 
Gambar di atas merupakan salah satu perbandingan visual dari tas bermerek asli dan tiruan dari segi bahan dan kualitas. Untuk logo sari tas bermerek asli biasanya menggunakan bahan dengan material yang lebih tebal dan tekstur yang lebih halus dengan grafir nama yang lebih rapi dibandingkan produk tiruan.

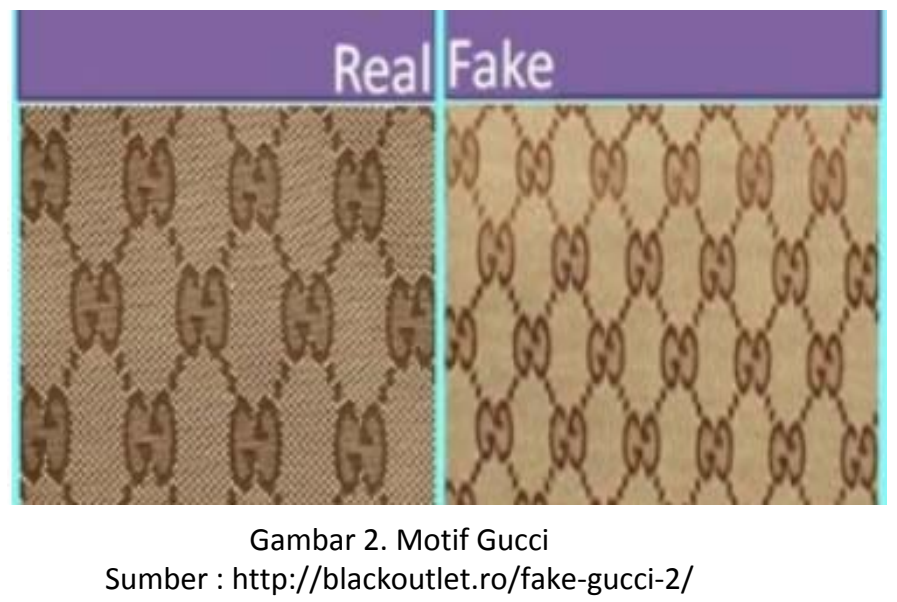

Dalam segi motif yang dibuat, untuk tas bermerek asli biasanya menggunakan detail yang lebih jelas dengan kontur warna yang lebih gelap dibandingkan tas bermerek tiruan. Warna dari tas bermerek tiruan biasanya cenderung mengarah kewarna kekuningan dengan skala motif yang agak kecil.

Selain sisi fungsionalitasnya tas juga digemari menurut sisi tampilan visualnya. Semakin bahan yang digunakan untuk menghias dan membuat tas bervariasi dan unik maka semakin banyak konsumen yang mencarinya dan dibandrol dengan harga yang relatif mahal. Bahkan menurut survey yang dilakukkan oleh Saveme4later.com dan dimuat dalam Daily Mail untuk mengidentifikasikan dominasi aplikasi belanja dimana konsumen bisa menyimpan produk favoritnya dan diikuti oleh 2.000 wanita. Dari survey tersebut diketahui 10 benda yang paling disukai wanita untuk dibeli yakni:

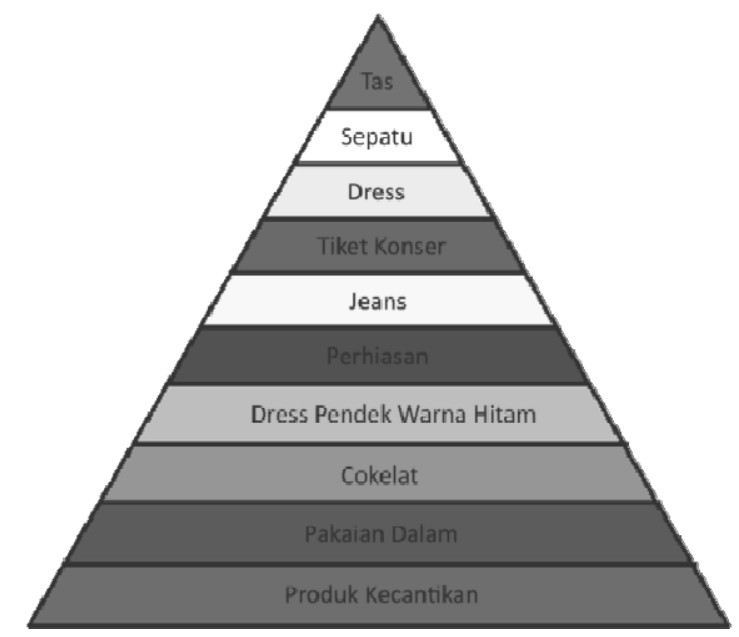

Gambar 3. Bagan 10 Benda yang Paling Disukai Wanita Sumber : http//: Wolipop. detik.com 
Survei tersebut menunjukan tingkat antusiasme wanita paling tinggi jatuh pada produk tas. Meskipun tas merupakan produk subtitusi namun kebutuhan tas bagi seorang wanita merupakan citra diri yang mampu mengangkat strata dan kelas sosial mereka ditengah masyarakat sosialita dan modern jaman sekarang.

\subsection{Persepsi Wanita terhadap Tas Bermerek}

Dalam survey yang dilakukan oleh Digital Luxury Group dan Luxury Society terkait dengan peringkat pencarian merek tas termewah lewat mesin pencarian seperti Google yang melibatkan 130 merek, 130 juta mesin pencari dan 8 negara ditemukan daftar brand tas mewah yang paling banyak dicari yaitu :

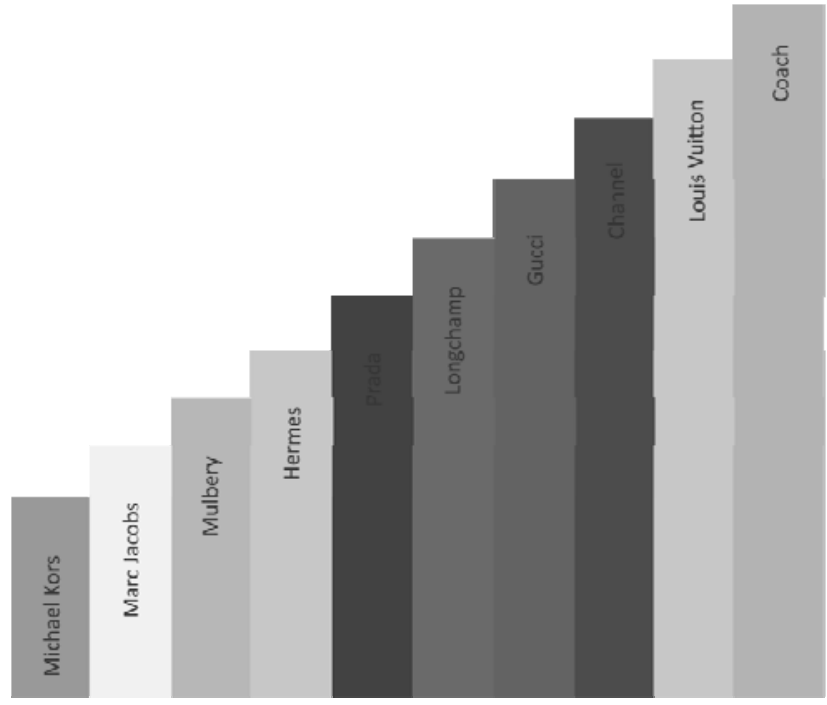

Gambar 4. Bagan 10 Brand Tas Mewah yang Banyak Dicari Sumber : http// Wolipop. detik.com

Daftar urutan tersebut menunjukkan tingkat konsumsi dan minat masyarakat terhadap sebuah produk bisa jadi didasarkan atas kepercayaan masyarakat akan produk brand yang sudah ternama. Minat masyarakat tersebut akan citra produk yang sudah ternama akhirnya memunculkan juga berbagai brand atau produk-produk keluaran terbaru yang memakai nama dan model hasil produksi yang hampir menyerupai produk-produk ternama tersebut.

Menurut Kotler, Bowen, dan Makens (1999) terdapat dua faktor yang mempengaruhi minat beli seseorang dalam proses pengambilan keputusan pembelian, yaitu situasi tidak terduga (Unexpected situation) dan sikap terhadap orang lain (Respect to Others). Kedua situasi faktor tersebut sebenarnya bisa saling berkorelasi satu dengan yang lain. Situasi yang tidak terduga bisa dapat terjadi apabila seseorang ingin menunjukan suatu sikap terhadap orang lain begitu juga sebaliknya. 


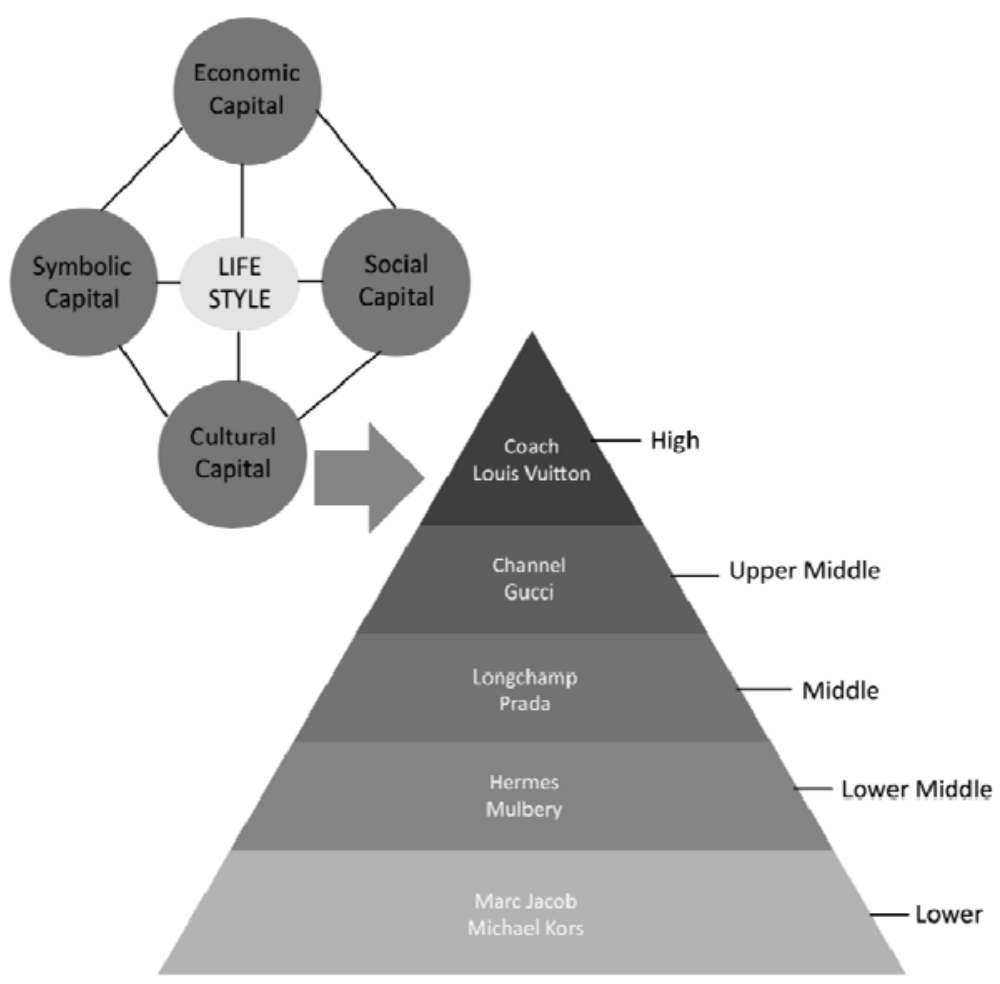

Gambar 5. Gambar Bagan Modal Sosial Sumber : http:// wollipop.com

Jika dilihat menurut klasifikasi modalnya (capital), bagan diatas menunjukkan bahwa produk tas termasuk kedalam modal sosial (social capital) dimana terdapat empat unsur didalamnya yaitu : (1) informasi, (2) pengaruh, (3) mandat sosial, dan (4) penguatan namun juga menunjukan diferensiasi objek. Keempat unsur tersebut ikut mempengaruhi konsumen dalam mengambil keputusan membeli sebuah produk. Jika didalamnya memiliki value yang cukup bagi konsumen untuk mewakili citra dirinya dan memberikan kepuasan tersendiri misalnya melalui label merek produk yang digusung meskipun bukan produk yang asli namun mampu menginformasikan kepada orang yang melihat produk tersebut bahwa produk tersebut merupakan produk kenamaan yang sedang populer atau menjadi tren dimasyarakat didukung dengan penguatan model yang dibuat semirip mungkin sehingga orang tidak mampu membedakan maka tas tersebut dirasa telah cukup mewakili pemiliknya sebagai modal sosial.

Merek adalah kelengkapan produk, jadi setiap produk harus memiliki merek, sehingga konsumen tidak mengalami kesulitan dalam mencari kembali produk tersebut. Merek juga mempunyai fungsi untuk membedakan kualitas produk yang satu dengan yang lainnya. Selain itu merek juga merupakan suatu jaminan dari produsen atas kualitas dari produk yang dihasilkan (Hermawan Kartawijaya, 1996:443). 
Merek disini bisa jadi merupakan sebuah pola pikir yang dihasilkan produsen ketika membuat suatu produk yang memiliki karakter atau nilai sendiri dihadapannya kemudian diolah dengan memberikannya identitas. Merek menurut produsen juga merupakan jaminan kualitas yang dia gusung disamping segi estetikannya. Sedangkan dari sudut pandang konsumen, konsumen melihat merek berdasarkan pengalaman yang ia dapat ketika berada diranah publik sekaligus penilaian konsumen terhadap kualitas barang tersebut.

\subsection{Kaitannya dengan Hukum Gestalt}

Banyaknya persaingan dunia bisnis tas antara produsen tas berkelas asli dengan produsen tas berkelas replika menjadi sebuah fenomena tersendiri. Mereka bersaing dalam hal penekanan produksi, harga, bahan dan model yang dihasilkan. Imbasnya untuk mensiasati tingkat keinginan atau hasrat para konsumen wanita dalam memiliki produk tas berkelas yang harganya relatif tidak bisa dijangkau oleh kantong kebanyakan para wanita, akhirnya para produsen lokal mulai memanfaatkan hal tersebut yakni dengan menyediakan produk replika duplikat dari produk tas berkelas original untuk mencari keuntungan sebesar-besarnya yakni dengan memperbanyak volume produksi dan penekanan harga yang jauh lebih terjangkau ketimbang produk originalnya. Fenomena ini bisa dilihat persamaanya dengan melihat hukum-hukum Gestalt dalam melihat bentuk yang terdiri dari empat hukum yang pokok (F. Patty, 1982: 99-100) yakni :

a. Hukum kedekatan. Yaitu penyatuan bentuk selalu terjadi berdasarkan kedekatan dalam formasi objek.

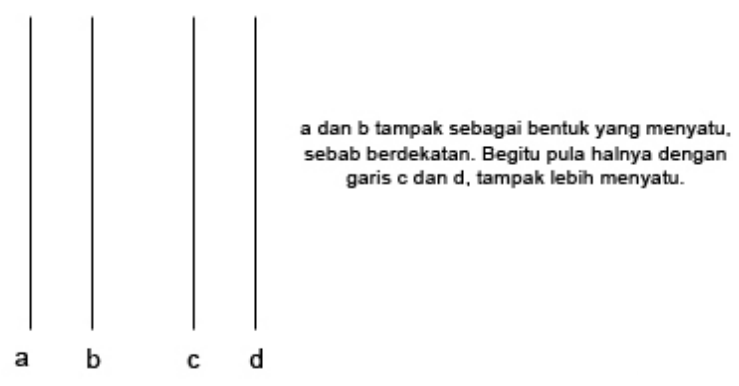

Gambar 6. Hukum Kedekatan

b. Hukum persamaan. Penyatuan bentuk terjadi berdsarkan kesamaan bentuk atau unsur-unsur objek penglihatan.

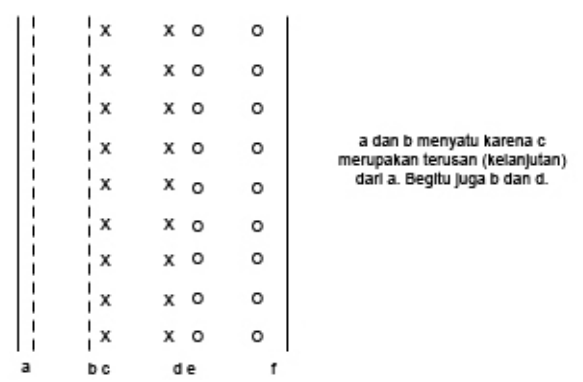

Gambar 7. Hukum Persamaan 
c. Hukum ketutupan. Yaitu pengelompokkan bentuk atau Gestalt timbul karena ketutupan unsur-unsur objek dari unsur-unsur yang lain.

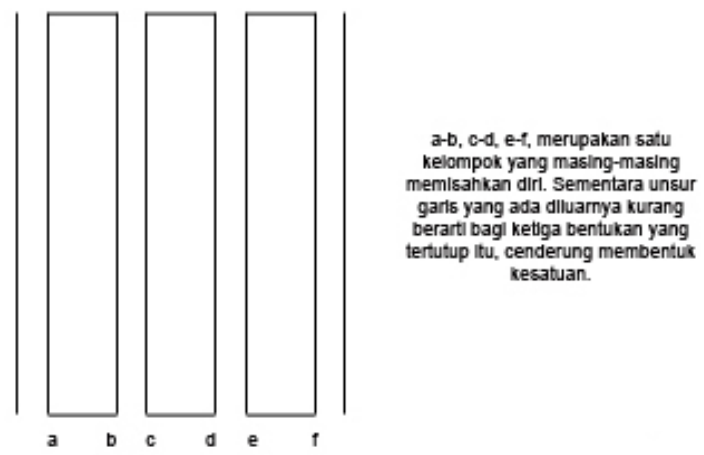

Gambar 8. Hukum Ketutupan

d. Hukum kontinuitas. Yaitu penyatuan bentuk timbul karena kontinuitas (kelangsungan) unsur satu dengan unsur lainya pada objek pengamatan.

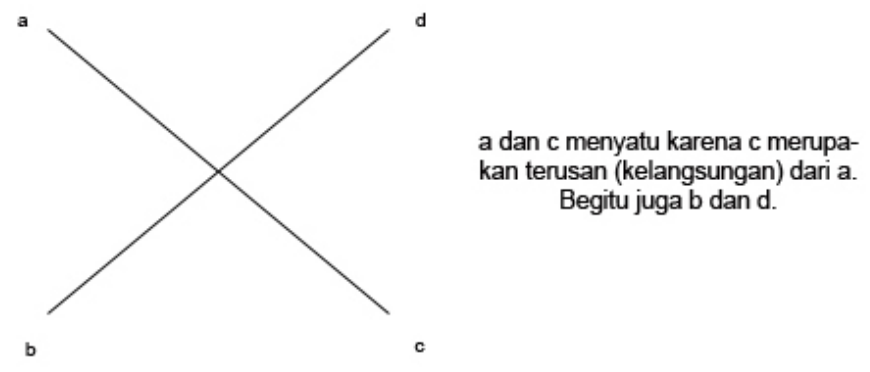

Gambar 9. Hukum Kontinuitas

Dalam kasus munculnya banyak produsen lokal yang memproduksi tas berkelas replika yang mirip sekali dengan produk tas berkelas original ini menggusung hukum Gestalt yang kedua dan keempat yakni hukum persamaan dan hukum kontinuitas. Hukum persamaan diindikasikan lewat kesamaan bentuk dan unsur-unsur objek penglihatan. Kesamaan bentuk mulai dari model meskipun dengan bahan yang berkualitas dibawah produk original membuat konsumen mempersepsikan unsur kesamaan tersebut lewat objek penglihatan visualnya (model) sehingga menimbulkan kesan objek replika yang dilihatnya masih berada dalam satu rumpun dengan produk originalnya. Sedangkan hukum kontinuitas terlihat dari keberlangsungan konsumen memandang objek tidak hanya satu kali tetapi sering. Hal ini memunculkan persepsi penyatuan objek dimana produk replika yang berada dihadapannya adalah produk original. Terkait juga dengan survey yang menunjukan wanita sekarang tidak menghambur-hamburkan uang mereka untuk berbelanja secara impulsif namun setidaknya membutuhkan dua kali kunjungan ke toko sebelum benar-benar membawa pulang tas tersebut. 
Bisnis produsen lokal ini yang memanfaatkan peluang pasar dengan membaca keadaan lingkungan sekitarnya menimbulkan konsep habitus dimana produsen lokal dibekali serangkaian skema atau pola yang diinternalisasikan dan mereka gunakan untuk merasakan, memahami, menyadari dan menilai dunia sosial. Terkait dengan Teori Habitus dari Bourdieu yang ingin menjembatani subyektivisme dan objektivisme. Konsumen dan produk dijembatani hasratnya untuk dapat saling menjalin keterkaitan emosional lewat produk yang dihasilkan oleh produsen dengan mengkondisikan dan melihat lingkungan yang sedang berkembang. Mata yang terbiasa melihat lingkungan sekitarnya seperti apa, akan diajak dalam konsep kebiasaan (habitus). Semakin sering seseorang secara kontinyu melihat hal-hal yang sama seperti kesehariannya maka ia akan semakin terbawa dalam arus keterpengaruhannya terhadap lingkungan. "Habitus menunjuk pada seperangkat kecenderungan (disposition), yang diciptakan dan dirumus ulang berdasarkan struktur objektif dan sejarah personal (personal history). (Richard Harker, 1990)"

Dalam konsep desain yang digusung oleh produsen lokal merupakan bagian dari ide yang ia dapatkan dengan melihat kecenderungan pasar dimana desain yang berasal dari produk yang sudah ternama atau berkelas akan membawa konsumen menempatkan dirinya (disposisi) sesuai dengan pembawaan kelasnya berdasarkan transformasi pengalaman yang ia dapatkan meskipun ia menyadari bahwa itu semua merupakan hasil rekayasa dari produk replika yang ia buat. Disini produsen dari tas berkelas yang original memang sepenuhnya tidak terlalu dirugikan karena sebagian dari mereka memiliki sertifikat atau tanda pengenal asli dengan harga produk yang jauh lebih tinggi ketimbang tas berkelas replika.Mekipun produk yang mereka hasilkan terbatas atau relatif sedikit itu menjadi sebuah ciri atau karakter merek yang mereka gusung yang seolah menunjukkan produk yang mereka miliki hanya untuk kalangan jet set atau berkelas saja. Namun bagi para produsen lokal yang memalsukan dan konsumen yang membeli tas berkelas replika harus berhati-hati karena sekarang terdapat ancaman hukuman penjara jika memalsukan maupun memilikinya. Pembeli tas merek 'abal-abal' ini (tas berkelas replika) bisa dikenai pasal 481 KUHP karena dianggap sengaja membeli barang dari hasil kejahatan. Pasal tersebut juga menjerat bagi yang memiliki tas KW lebih dari dua akan dianggap sebagai kebiasaan memanfaatkan barang ilegal. Sedangkan untuk produsen tas KW juga akan terancam hukuman maksimal lima tahun penjara dan denda hingga Rp. 1 miliar berdasarkan Undang-Undang Hak Atas Kekayaan Intelektual (HAKI). 


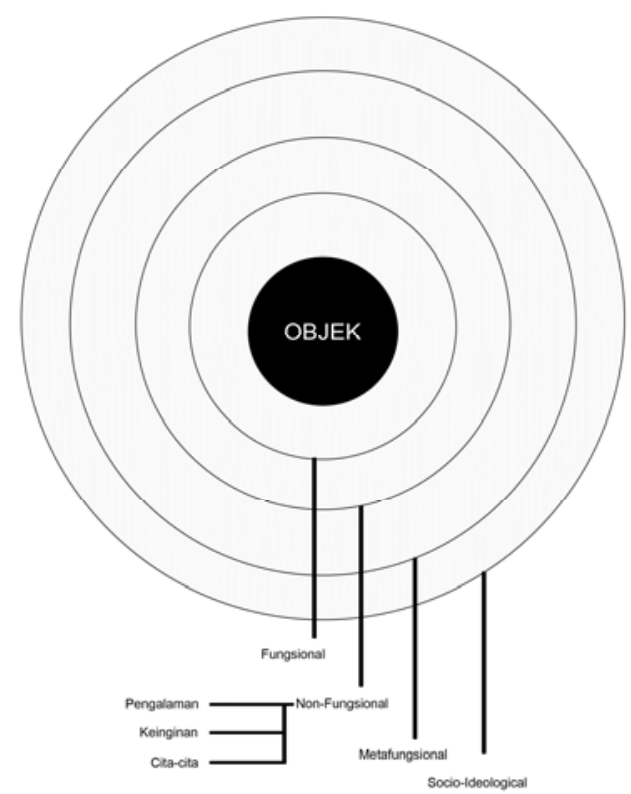

Gambar 10. Sistem Objek

Menilik dari sistem objek yang membawanya dalam kasus ini termasuk ke dalam The Non-Functional System dimana objek tidak hanya dilihat sebatas fungsionalitasnya saja akan tetapi ranah ekspresinya juga yang mana jika memakai objek tersebut (tas) mampu menjembatani individu berdasarkan kompromi dari pengalaman, keinginan dan cita-citanya. Dimana tadinya masyarakat kalangan bawah tidak mampu merasakan tingkat kesenangan dari memiliki barang-barang berkelas akhirnya mampu merasakannya lewat tangan para produsen lokal yang mampu menyulap produknya kedalam replika produk berkelas yang hampir sama dengan produk berkelas original meskipun yang didapat berupa kepuasan yang semu semata karena disamping itu semua terdapat ancaman hukum yang menyertainya terkait dengan produk tiruan yang tidak sesuai dengan produk yang telah dipatenkan.

\section{KESIMPULAN}

Tas menjadi sebuah ikon penanda tingkatan kelas atau fashion bagi wanita dewasa ini ditengah masyarakat sosialita dan modern. Ditengah fenomena resesi moral masyarakat akan banyaknya produk tiruan atau replika membuat tas menjadi salah satu produk yang dimanfaatkan oleh produsen lokal untuk mencari keuntungan sebesar-besarnya. Fenomena tersebut akhirnya terus menjadi habitus (kebiasaan) yang sulit dihilangkan hingga timbul ancaman hukum dari pemerintah. Namun sayangnya, komoditi tas berkelas replika terus beranak pinak tanpa memperhatikan ancaman hukum hingga saat ini dikarenakan salah satu faktor juga yakni banyaknya pelanggaran tersebut menjadikan oknum-oknum hukum sulit untuk menanganinya. 
Tas menimbulkan fetisisme tersendiri bagi wanita hingga memunculkan social difference dikalangan wanita berdasarkan kepemilikan produk tersebut. semakin produk yang ia miliki banyak dicari dan memiliki brand yang ternama maka semakin tinggi pula tingkat penghargaan atas dirinya didalam masyarakat. Terkait dengan sistem objek yang mendasarinnya masuk kedalam The Non-Functional System dikarenakan produk tersebut sekarang bukan lagi diapresiasikan dengan dominan nilai fungsionalitasnya saja tetapi juga didasarkan faktor ekspresi, pengalaman, keiginan dan cita-cita atas kepemilikan produk tersebut.

\section{DAFTAR PUSTAKA}

A. Gazali, Prof., MA., Ilmu Jiwa, Ganaco, Bandung, 1970.

F. Patty, Prof., MA., et. al., Pengantar Psikologi Umum, Usaha Nasional, SurabayaIndonesia, 1982.

Kotler, P., Bowen, J., dan Makens, J. 1999. Marketing for Hospitality and Tourism. Second Edition. Prentice Hall Inc. Upper Saddle River, New Jersey. Slameto, Belajar dan Faktor-Faktor yang Mempengaruhi, hlm. 56.

\section{Website :}

http://blackoutlet.ro/fake-gucci-2/

http://wolipop.detik.com/read/2011/09/26/163422/1730761/1141/1-dari-4-wanitalebih-pilih-beli-tas-mahal-ketimbang-sepatu http://wolipop.detik.com/read/2012/07/09/153411/1961149/233/10-merek-tasmewah-yang-paling-dicari-di-dunia 
Andharupa, Jurnal Desain Komunikasi Visual \& Multimedia. Vol.01 No.02 Tahun 2015 